\title{
Standardisation of RTS beverage from reconstituted cashew apple-based blended juice powder along with Sugandi
}

\author{
K. Umamaheswara Rao*, B. Prasanna Kumar, D.V. Swami, B. Salomi Sunnetha, \\ K. Uma Krishna and D.D. Smith \\ AICRP on Cashew, Cashew Research Station, Dr. Y.S.R. Horticultural University, Bapatla-522 101, \\ Andhra Pradesh, India
}

(Manuscript Received: 12-10-2020, Revised: 21-12-2020, Accepted: 15-01-2021)

\begin{abstract}
Cashew has commercial value for its nut and peduncle (false fruit), known as cashew apple. Requirements of consumers considering convenience, food safety, health benefits and sensory quality have increased demand for fruit juices. Instant juice powders can meet consumer requirements being cheap to transport and with prolonged shelf life. Then the blended juice was mixed with maltodextrin @15 per cent, i.e., $15 \mathrm{~g}$ for $100 \mathrm{~mL}$ of blended juice by proper homogenisation. The roots of the sugandi (Swallow root - Decalepsis hamiltonii) were collected, cleaned thoroughly and the central white portion of the roots was discarded. Among the blended juice treatment combinations, the highest $\mathrm{pH}$ of 3.45 was recorded in $\mathrm{B}_{3}(75 \%$ cashew apple juice $+25 \%$ pineapple juice powder at $150^{\circ} \mathrm{C}$ inlet temperature with a flow rate of $10 \mathrm{~mL} \mathrm{~min}^{-1}$ ). The ready-to-serve (RTS) beverage, along with sugandi stored under refrigerated condition, were free from microbial proliferation till the end of the storage period ( $60^{\text {th }}$ day of storage), indicating its fitness for consumption with maximum flavour, taste and overall acceptability.
\end{abstract}

Keywords: Beverage, blended juice powder, cashew apple RTS, sugandi

\section{Introduction}

Cashew (Anacardium occidentale L.), belonging to the family Anacardiaceae, one of the important dry land plantation crops cultivated in India, ranks third in its export value among internationaly traded kernels. It is native to Brazil and well distributed in both tropical and sub-tropical regions of the world. In India, it covers an area of 10.6 lakh hectares with an annual nut production of 8.17 lakh tonnes with average productivity of 753 $\mathrm{kg} \mathrm{ha}^{-1}$. In India, it is grown in 17 states which include Kerala, Tamil Nadu, Maharashtra, Goa, Karnataka, Andhra Pradesh, Orissa, West Bengal, Chattisgarh, Jharkhand, Tripura, Meghalaya and Assam (Hubbali, 2019). In Andhra Pradesh, it is cultivated in an area of 1.85 lakh hectares with an annual nut production of one lakh tonnes and average productivity of $646 \mathrm{~kg} \mathrm{ha}^{-1}$ (Hubbali, 2019).
In Andhra Pradesh, cashew is mostly grown in Srikakulam, Vizianagaram, Vishakhapatnam, East Godavari, West Godavari, Krishna, Guntur, Prakasam and Nellore districts.

Cashew has commercial value for its nut and peduncle (false fruit), known as cashew apple. The production of cashew apple in India is about 65.4 lakh tones (Hubbali, 2019). The cashew apple, the pseudo-fruit, is fibrous, juicy and weighs approximately 6-8 times the nut. Cashew apples are quite nutritious, rich in polyphenols, minerals, organic acids, carbohydrates, pigments and vitamins (Chempakam, 1983). It has nutritional importance for its therapeutic properties and value-added products. Still, around 90 per cent of the harvest gets wasted (Azevedo and Rodriguez, 2000). The remaining 10 per cent of harvested apple is either consumed as fresh or processed industrially into a variety of products such as juices, syrups,

*Corresponding Author: umamahesh_horti@yahoo.com 
canned fruits, pickles, jams, chutneys, candies, toffees, ice creams, vinegar, marmalade and distilled products (Maciel et al., 1986; Nanjundaswamy, 1984). Juice blending is one of the best methods to improve the nutritional quality of juice. It can improve the vitamins and mineral contents depending upon the kind and quality of fruits and vegetables used (Carvalho et al., 2007).

Requirements of the consumers considering convenience, food safety, health benefits, and sensory quality have increased demand for fruit juices. Still, most consumers require ready-to-use or easy-to-prepare products. Instant juice powders can meet consumer requirements being cheap to transport and with a prolonged shelf life, as reported by Cano-Chauca et al. (2005). Moreover, Shreshta et al. (2007) enumerated the benefits and economic potential of fruit juice powders over their liquid counterparts with reduced volume or weight, reduced packaging, easy handling and transportation and much longer shelf life. Besides, their physical state provides a stable, natural and easily dosable ingredient, which generally finds usage in many foods and pharmaceutical products as flavouring and colouring agents.

\section{Materials and methods}

\section{Extraction of cashew apple juice}

The ripened and blemish-free cashew apples were cut into pieces and fed to the mechanical juice extractor. The cut pieces were pressed out using a motor-operated screw type juice extractor, and the juice obtained was thus collected into a stainless steel container before clarification.

\section{Clarification of juice}

Cashew apple juice is highly perishable when fresh, often spoils within a day. The juice contains tannins, which causes astringency and should be removed to improve the quality of the juice. The cashew apple juice was strained through a muslin cloth and collected into a wide mouth stainless steel container. The clarifying agent, cooked sago@2g + citric acid@2.5 g per litre of juice,was added slowly by stirring the juice in a circular motion till the entire juice formed into curd-like precipitate. The precipitate was allowed to stand for eight hours, and the clear supernatant was collected slowly without disturbing the residue. The clear juice obtained was strained through a muslin cloth and used in this experiment.

\section{Preparation of different blended juices}

The fruit juices prepared from mango, orange, pineapple and cashew apple were blended in the ratio of 75:25 viz., cashew apple juice with other juice containing 40 treatments and observations were recorded for different parameters. The blended juice was prepared by addition of cashew apple juice with mango juice in the proportion of $75 \mathrm{~mL}+25$ $\mathrm{mL}$, cashew apple juice with orange juice in the proportion of $75 \mathrm{~mL}+25 \mathrm{~mL}$, cashew apple juice with pineapple juice in the proportion of $75 \mathrm{~mL}+$ $25 \mathrm{~mL}$ and 100 per cent cashew apple juice alone.

\section{Carriers}

The carrier material used for microencapsulation was maltodextrin (MD), obtained from Himedia Laboratories Limited, India. Maltodextrin is a non-sweet, soluble, white to an off white coloured, slightly hygroscopic powder having 20 dextrose equivalence. MD was used because of its neutral colour, taste and relatively low cost. It is considered hydrolysed starch, and it is obtained by the action of either acids or enzymes. The addition of MD in food material before spray drying can reduce stickiness and agglomeration problems during the storage of the end product.

\section{Addition of maltodextrin and homogenisation}

The blended juice was mixed with maltodextrin @ 15 per cent, i.e., $15 \mathrm{~g}$ for $100 \mathrm{~mL}$ of blended juice by proper homogenisation as reported by Rafeekher et al. (2015). Juice carrier concentration in the ratio of 40:60 based on total soluble solids of juice was subjected to spray drying by mixing $100 \mathrm{~mL}$ of juice and carrier material. After adding maltodextrin to the blended cashew apple juice, it was homogenised thoroughly using a glass rod as a stirrer and was used for powder preparation.

\section{Production of blended juice powder}

At specified inlet air temperature, water was fed into the nozzle atomiser by a peristaltic pump. The feed rate of water adjusted to maintain the outlet temperature of the air at $88 \pm 2{ }^{\circ} \mathrm{C}$ throughout the 
drying process. When the inlet air temperature was the desired temperature, and the outlet air temperature was stabilised at $88 \pm 2{ }^{\circ} \mathrm{C}$, the prepared feed mix was fed into the feed bowl. The feed mix after atomisation was mixed thoroughly with the hot air in the drying chamber and instantly converted into powder. The powder particles were collected in the conical bottom of the drying chamber and then carried by air into the cyclone separator. In the cyclone separator, powder particles from the air and get collected in a jar. The air was let out into the atmosphere. Loose powder remaining in the drying chamber also was collected by capping with a clean cloth. Powder form the cyclone separator and loose powder from the chamber was separately weighed and then mixed.

Spray-dried juice powder was collected in glass bottles and evaluated for their physical and chemical parameters. Statistical analysis was done based on a three-factor, completely randomised design and three best treatments were selected based on powder recovery from blended juice powder combinations and one from 100 per cent cashew apple juice powder.

\section{Reconstitution of the blended cashew apple juice powder for RTS beverage along with sugandi}

The four best treatments were selected based on the blended juice powder recovery by the spray drying technique used. The same was prepared for the reconstitution of the powder for the preparation of RTS beverage with sugandi with the following treatments.

\begin{tabular}{|c|c|}
\hline $\mathrm{B}_{1}$ & $\begin{array}{l}75 \% \text { cashew apple juice }+25 \% \text { pineapple juice at } 170{ }^{\circ} \mathrm{C} \\
\text { for } 10 \mathrm{~mL} \mathrm{~min}{ }^{-1}\end{array}$ \\
\hline $\mathrm{B}_{2}$ & $\begin{array}{l}75 \% \text { cashew apple juice }+25 \% \text { pineapple juice at } 160^{\circ} \mathrm{C} \\
\text { for } 10 \mathrm{~mL} \mathrm{~min}{ }^{-1}\end{array}$ \\
\hline $\mathrm{B}_{3}$ & $\begin{array}{l}75 \% \text { cashew apple juice }+25 \% \text { pineapple juice at } 150{ }^{\circ} \mathrm{C} \\
\text { for } 10 \mathrm{~mL} \mathrm{~min}{ }^{-1}\end{array}$ \\
\hline $\mathrm{B}_{4}$ & $100 \%$ cashew apple juice at $150{ }^{\circ} \mathrm{C}$ for $10 \mathrm{~mL} \mathrm{~min}^{-1}$ \\
\hline $\mathrm{C}_{1}$ & Ambient condition \\
\hline $\mathrm{C}_{2}$ & Refrigerated condition \\
\hline $\mathrm{S}_{1}$ & 0 day (initial day) \\
\hline $\mathrm{S}_{2}$ & $15^{\text {th }}$ day of storage \\
\hline $\mathrm{S}_{3}$ & $30^{\text {th }}$ day of storage \\
\hline $\mathrm{S}_{4}$ & $45^{\text {th }}$ day of storage \\
\hline $\mathrm{S}_{5}$ & $60^{\text {th }}$ day of storage \\
\hline
\end{tabular}

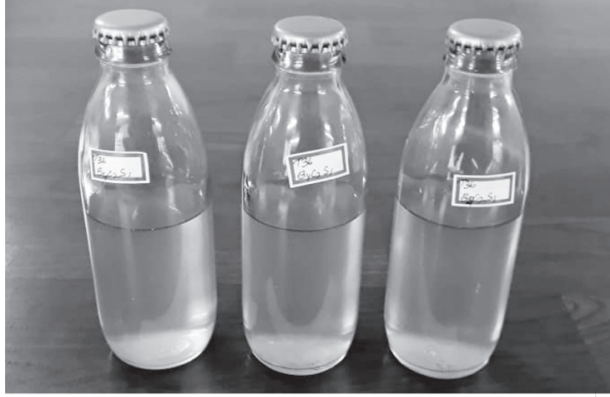

At initial day of storage

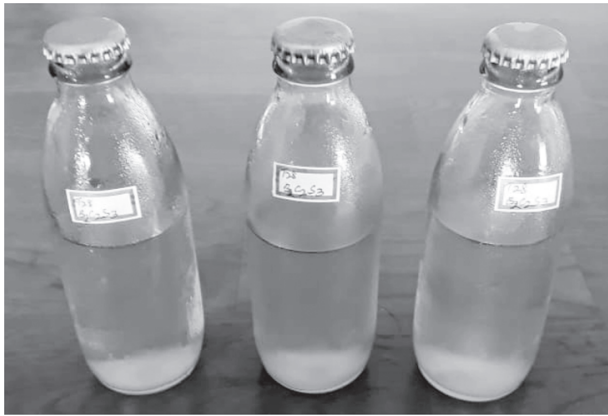

At $15^{\text {th }}$ day of storage

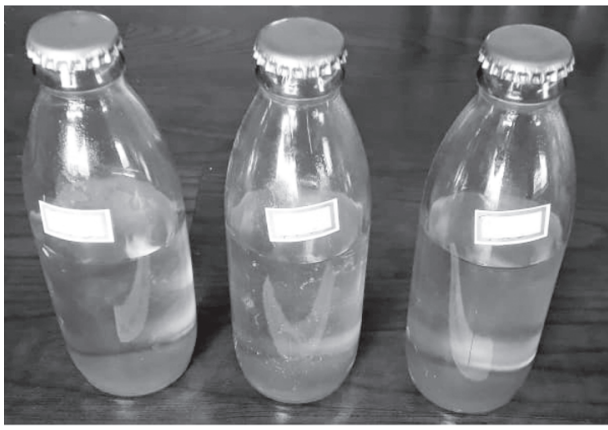

At $30^{\text {th }}$ day of storage

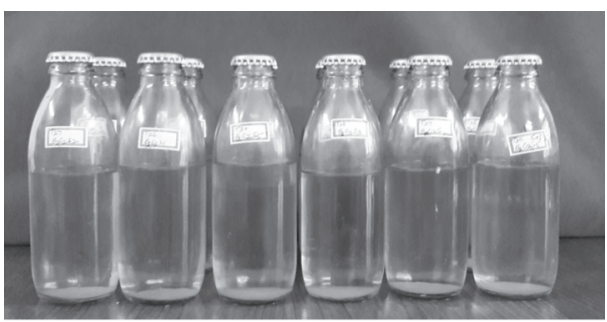

At $45^{\text {th }}$ day of storage

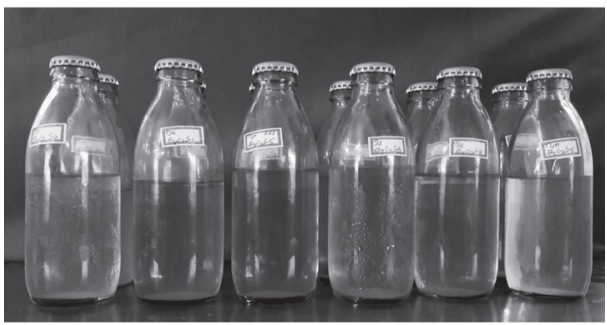

View of Blended RTS beverage prepared along with sugandi at initial, $15^{\text {th }}$ and $30^{\text {th }}$ day of storage under refrigerated condition 
Factor-I (Blended juice treatment combinations)

B $1-75 \%$ cashew apple juice $+25 \%$ pineapple juice at $170{ }^{\circ} \mathrm{C}$ inlet temperature with flow rate of $10 \mathrm{~mL} \mathrm{~min}^{-1}$

$\mathrm{B}_{2}-75 \%$ cashew apple juice $+25 \%$ pineapple juice at $160{ }^{\circ} \mathrm{C}$ inlet temperature with flow rate of $10 \mathrm{~mL} \mathrm{~min}^{-1}$

$\mathrm{B}_{3}-75 \%$ cashew apple juice $+25 \%$ pineapple juice at $150{ }^{\circ} \mathrm{C}$ inlet temperature with flow rate of $10 \mathrm{~mL} \mathrm{~min}{ }^{-1}$

$\mathrm{B}_{4}-100 \%$ cashew apple juice at $150^{\circ} \mathrm{C}$ inlet temperature with

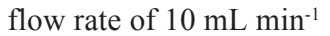

Factor-II (Storage condition)

$\mathrm{C}_{1}$ - Ambient condition

$\mathrm{C}_{2}$ - Refrigerated condition

Factor-III (Days of storage)

$\mathrm{S}_{1}$ : 0 day

$\mathrm{S}_{2}: 15^{\text {th }}$ day of storage

$\mathrm{S}_{3}: 30^{\text {th }}$ day of storage

$\mathrm{S}_{4}: 45^{\text {th }}$ day of storage

$\mathrm{S}_{5}: 60^{\text {th }}$ day of storage

\section{Procedure for preparation of sugandi root extract}

The roots of the sugandi (Swallow root Decalepsis hamiltonii) were collected and cleaned thoroughly, and the central white portion of the roots was discarded. The dark outer portion of the roots was collected (250 g) and sun-dried for a day. These roots were soaked in 2 litres of water overnight. On soaking, the liquid turns a dark colour. The next morning, the roots were boiled along with the soaked water until it reduced to half of its original quantity. The liquid was strained with a doublelayered cheese cloth so that no particles trickled down. The strained liquid was poured into another clean heavy bottomed vessel. To this liquid, added one $\mathrm{kg}$ of sugar and heated till it turns slightly thick and sticky, approximately for $15 \mathrm{~min}$ on low, medium flame. Then it was cooled and stored the dark brown liquid in a clean bottle.

\section{Preparation of ready to serve (RTS) beverage}

Blend combination $B_{1}$ contains one gram of spray-dried, blended cashew apple juice powder (75\% cashew apple juice $+25 \%$ pineapple juice spray-dried at $170{ }^{\circ} \mathrm{C}$ with a flow rate of $10 \mathrm{~mL}$ min $^{-1}$ ) added with $2.5 \mathrm{~g}$ of sugar along with $2.5 \mathrm{~mL}$ of sugandi concentrate and $94 \mathrm{~mL}$ of water and prepared $100 \mathrm{~mL}$ RTS. The blend combination $\mathrm{B}_{2}$ contains one gram of spray-dried blended cashew apple juice powder $(75 \%$ cashew apple juice $+25 \%$ pineapple juice spray-dried at $160^{\circ} \mathrm{C}$ with a flow rate of $10 \mathrm{~mL} \mathrm{~min}^{-1}$ ) added with $2.5 \mathrm{~g}$ of sugar along with $2.5 \mathrm{~mL}$ of sugandi concentrate and $94 \mathrm{~mL}$ of water and prepared $100 \mathrm{~mL}$ RTS. The blend combination $\mathrm{B}_{3}$ contains one gram of spray-dried blended cashew apple juice powder $(75 \%$ cashew apple juice $+25 \%$ pineapple juice spray-dried at $150^{\circ} \mathrm{C}$ with a flow rate of $10 \mathrm{~mL} \mathrm{~min}^{-1}$ ) added with $2.5 \mathrm{~g}$ of sugar along with $2.5 \mathrm{~mL}$ of sugandi concentrate and $94 \mathrm{~mL}$ of water and prepared 100 $\mathrm{mL}$ RTS. The blend combination $\mathrm{B}_{4}$ contains one gram of spray-dried cashew apple juice powder $\left(100 \%\right.$ cashew apple juice spray-dried at $150{ }^{\circ} \mathrm{C}$ with a flow rate of $10 \mathrm{~mL} \mathrm{~min}^{-1}$ ) added with $2.5 \mathrm{~g}$ of sugar along with $2.5 \mathrm{~mL}$ of sugandi concentrate and $94 \mathrm{~mL}$ of water and prepared $100 \mathrm{~mL}$ RTS. These were hot filled in sterilised bottles of $200 \mathrm{~mL}$ size and crown corked and heat processed in boiling water at $65^{\circ} \mathrm{C}$ for $30 \mathrm{~min}$ then cooled and stored (Srivastava and Kumar, 2002).

\section{Storage of RTS beverage}

The RTS beverage prepared from different treatments of the experiment were hot-filled in a sterilised bottle of $200 \mathrm{~mL}$ size and crown corked and heat processed in boiling water at $65{ }^{\circ} \mathrm{C}$ for $30 \mathrm{~min}$ then cooled. These were stored at two storage conditions. Hot filled bottles were stored under the ambient condition at room temperature at $30^{\circ} \mathrm{C}$ for up to 60 days and recorded the physicochemical properties of RTS at 15 days interval. Hot filled bottles were stored under the refrigerated condition at $4{ }^{\circ} \mathrm{C}$ for up to 60 days, and the physico-chemical properties of RTS were recorded at 15 days interval.

The RTS beverages of different treatments were stored in ambient and refrigerated conditions. The quality parameters of the beverage were studied at different days of storage, i.e., 0, 15, 30, 45 and 60 days after storage. The experiment was designed in 3-factorial CRD with two replications comprising 40 treatments.

\section{Results and discussion}

The study describes the utilisation of cashew apple juice blended with other fruit juice powder. The blended juice powder prepared with pineapple combination, which found to be the best and best treatment of $100 \%$ cashew apple juice powder by spray drying technique, is used to prepare RTS beverage and sugandi. 
pH

Among the blended juice treatment combinations, the highest $\mathrm{pH}$ of 3.45 was recorded in $\mathrm{B}_{3}$, and the lowest (3.43) was recorded in $\mathrm{B}_{2}$. Among the different storage conditions, the highest $\mathrm{pH}$ of 3.45 was recorded in $\mathrm{C}_{2}$ (refrigerated condition), and the lowest of 3.42 was recorded in $\mathrm{C}_{1}$ (ambient condition). Among the different days of storage, the highest $\mathrm{pH}$ of 3.53 was recorded in $\mathrm{S}_{1}$ (0 days of storage), and the lowest of 3.38 was recorded in $\mathrm{S}_{5}\left(60^{\text {th }}\right.$ day of storage) (Table 1$)$.

The $\mathrm{pH}$ of different blended juice treatment combinations varied from 3.51 to 3.54 on the initial day of storage. Among the interaction effect of blended juice treatment combinations, storage conditions, and days of storage recorded, the highest $\mathrm{pH}$ in treatment combination of $\mathrm{C}_{1} \mathrm{~B}_{2} \mathrm{~S}_{2}$ and the lowest was recorded in (Table 3 ).

The mean value of $\mathrm{pH}$ significantly increased from the initial day to the $60^{\text {th }}$ day of the storage period. Nath et al. (2005) observed similar results for kinnow ginger blended squash. Maia and Cecilia (2002) observed that $\mathrm{pH}$ increased in apple juice during storage due to the reduction of titrable acidity because both $\mathrm{pH}$ and titrable acidity were inversely proportional to each other. Rehman et al. (2014) described that the possible reason for increased $\mathrm{pH}$ with prolonged storage of kinnow juice might be the acid hydrolysis of the polysaccharides into mono-saccharine disaccharides, which are responsible for the increase in sweetness and decrease in sourness. These results conform to Muhammad et al. (2018), who worked with orange date blended squash.

\section{Total soluble solids ( $\left.{ }^{\circ} \mathrm{Brix}\right)$}

Among the blended juice treatment combinations, the highest total soluble solids of $10.45^{\circ}$ Brix were recorded in $\mathrm{B}_{4}$ followed by $\mathrm{B}_{3}$ $\left(10.33^{\circ}\right.$ Brix) and the lowest was recorded in $\mathrm{B}_{1}$. Among the different storage conditions, the highest total soluble solids was recorded in $\mathrm{C}_{1}\left(10.41^{\circ} \mathrm{Brix}\right)$, and the lowest was recorded in $\mathrm{C}_{2}$. Among the different storage days, the highest total soluble solids were recorded in $\mathrm{S}_{5}$, and the lowest was recorded in $\mathrm{S}_{1}$ (Table 1).

The total soluble solids of different blended juice treatment combinations varied from 10.00 to

Table 1. Effect of blended juice powders obtained from spray drying on storage conditions and days on quality parameters of RTS beverage mixed with sugandi.

\begin{tabular}{|c|c|c|c|c|c|c|c|c|}
\hline Treatments & pH & $\begin{array}{c}\text { TSS } \\
\text { (p brix) }\end{array}$ & $\begin{array}{c}\text { Titrable } \\
\text { acidity } \\
(\%) \\
\end{array}$ & $\begin{array}{c}\text { Reducing } \\
\text { sugars } \\
(\%) \\
\end{array}$ & $\begin{array}{c}\text { Total } \\
\text { sugars } \\
(\%)\end{array}$ & $\begin{array}{l}\text { TSS/Acid } \\
\text { ratio }\end{array}$ & 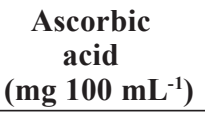 & $\begin{array}{c}\text { Tannins } \\
\left(\mathrm{mg} \mathrm{mL}^{-1}\right)\end{array}$ \\
\hline B1 & 3.44 & 10.24 & 0.49 & 3.22 & 8.92 & 21.43 & 147.15 & 1.018 \\
\hline B2 & 3.43 & 10.33 & 0.47 & 3.25 & 9.00 & 22.14 & 150.31 & 0.995 \\
\hline B3 & 3.45 & 10.42 & 0.48 & 3.29 & 9.09 & 21.99 & 152.05 & 0.990 \\
\hline B4 & 3.43 & 10.45 & 0.74 & 3.37 & 9.23 & 13.99 & 196.98 & 1.161 \\
\hline $\operatorname{SEm} \pm$ & 0.005 & 0.01 & 0.003 & 0.005 & 0.004 & 0.03 & 0.42 & 0.002 \\
\hline CD (0.05) & 0.014 & 0.04 & 0.008 & 0.013 & 0.012 & 0.10 & 1.21 & 0.007 \\
\hline C1 & 3.42 & 10.41 & 0.54 & 3.27 & 9.06 & 20.11 & 161.18 & 1.039 \\
\hline $\mathrm{C} 2$ & 3.45 & 10.31 & 0.55 & 3.30 & 9.06 & 19.67 & 162.06 & 1.043 \\
\hline $\operatorname{SEm} \pm$ & 0.003 & 0.01 & 0.002 & 0.003 & 0.003 & 0.02 & 0.30 & 0.002 \\
\hline CD (0.05) & 0.010 & 0.03 & 0.006 & 0.009 & NS & 0.07 & 0.85 & NS \\
\hline S1 & 3.53 & 10.10 & 0.60 & 3.09 & 8.98 & 17.35 & 169.73 & 1.093 \\
\hline $\mathbf{S 2}$ & 3.50 & 10.20 & 0.57 & 3.18 & 9.02 & 18.55 & 165.16 & 1.067 \\
\hline $\mathbf{S 3}$ & 3.45 & 10.32 & 0.55 & 3.30 & 9.04 & 19.36 & 161.39 & 1.044 \\
\hline S4 & 3.38 & 10.44 & 0.53 & 3.41 & 9.10 & 20.56 & 157.68 & 1.010 \\
\hline S5 & 3.35 & 10.74 & 0.47 & 3.44 & 9.14 & 23.63 & 154.15 & 0.990 \\
\hline $\operatorname{SEm} \pm$ & 0.005 & 0.02 & 0.003 & 0.005 & 0.005 & 0.04 & 0.42 & 0.003 \\
\hline CD (0.05) & 0.016 & 0.04 & 0.009 & 0.015 & 0.013 & 0.11 & 1.19 & 0.008 \\
\hline
\end{tabular}


Table 2. Effect of blended juice powders obtained from spray drying on storage conditions and days on quality parameters of RTS beverage mixed with sugandi.

\begin{tabular}{lcccc}
\hline Treatments & Colour & Flavour & Taste & $\begin{array}{c}\text { Overall } \\
\text { acceptability }\end{array}$ \\
\hline B1 & 7.76 & 7.37 & 6.96 & 7.06 \\
B2 & 8.00 & 7.63 & 7.31 & 7.38 \\
B3 & 7.59 & 7.14 & 7.14 & 7.06 \\
B4 & 7.71 & 7.27 & 6.89 & 7.12 \\
\hline SEm \pm & 0.05 & 0.05 & 0.04 & 0.07 \\
CD (0.05) & 0.14 & 0.14 & 0.13 & 0.20 \\
\hline C1 & 7.61 & 7.06 & 6.70 & 6.63 \\
C2 & 7.92 & 7.62 & 7.45 & 7.67 \\
\hline SEm \pm & 0.03 & 0.03 & 0.03 & 0.05 \\
CD (0.05) & 0.09 & 0.10 & 0.09 & 0.13 \\
\hline S1 & 8.68 & 8.35 & 8.15 & 8.37 \\
S2 & 8.11 & 7.80 & 7.59 & 7.69 \\
S3 & 7.79 & 7.32 & 7.12 & 7.14 \\
S4 & 7.33 & 6.76 & 6.43 & 6.50 \\
S5 & 6.91 & 6.47 & 6.08 & 6.06 \\
\hline SEm \pm & 0.05 & 0.05 & 0.05 & 0.07 \\
CD (0.05) & 0.15 & 0.16 & 0.14 & 0.21 \\
\hline & & & &
\end{tabular}

$10.15^{\circ}$ Brix at the initial day of storage. Among the interaction effects of blended juice treatment combinations, storage conditions and days of storage recorded the highest total soluble solids in the treatment combination of $\mathrm{C}_{1} \mathrm{~B}_{4} \mathrm{~S}_{5}$ with 11.15 ${ }^{\circ}$ Brix followed by $\mathrm{C}_{1} \mathrm{~B}_{3} \mathrm{~S}_{5}$ with $11.00{ }^{\circ}$ Brix and the lowest was recorded in $\mathrm{C}_{1} \mathrm{~B}_{1} \mathrm{~S}_{2}$ with $10.10^{\circ} \mathrm{Brix}$ (Table 3).

The mean value of TSS has significantly increased from the initial day to $60^{\text {th }}$ day during the storage. Prasad and Mali (2000) observed the least increase in TSS under refrigerated storage of kinnow juice, and they reasoned the same due to reduced hydrolysis of polysaccharides and acids. Bhardwaj and Nandal (2014) had also reported similar findings, which showed that TSS of blended kinnow juice directly correlated with storage duration of storage and increase in TSS was higher at ambient condition due to the high rate of solubilisation or hydrolysis of acid into sugars. Similar findings have been reported by Deka and Sethi (2001) in mixed fruit juice spiced beverage, Singh and Mathur (1953) in cashew apple juice and Bhardwaj and Mukherjee (2012) in Kinnow juice. The hydrolysis of polysaccharides (starch and pectin) into simpler substances was responsible for the increase in TSS of mandarin ginger blended squash during storage (Nath et al., 2005). Sindumathi and Premalatha (2015) studied and observed the initial TSS content of flavoured papaya-pineapple blended RTS beverage was 15.0 ${ }^{\circ}$ Brix which was increased to $18.0^{\circ}$ Brix at 120 days of storage. Sasi Kumar (2015) studied the RTS made from a blend of Aloe vera and aonla fruit juice and revealed that total soluble solids increased gradually during storage.

\section{Titrable acidity (\%)}

Among the blended juice treatment combinations, the highest titrable acidity of 0.74 per cent was recorded in $\mathrm{B}_{4}$ and the lowest was recorded in $\mathrm{B}_{2}$. Among the different storage conditions, the highest titrable acidity (\%) was recorded in $\mathrm{C}_{2}$ of 0.55 per cent, and the lowest was recorded in $\mathrm{C}_{1}$. Among the different days of storage, the highest titrable acidity (\%) was recorded in $\mathrm{S}_{1}$ of 0.59 per cent, and the lowest was recorded in $\mathrm{S}_{5}$ of 0.47 per cent (Table 1)

The titrable acidity of different blended juice treatment combinations varied from 0.53 to 0.79 per cent on the initial day of storage. Among the interaction effects of blended juice treatment combinations, storage conditions and days of storage, the highest titrable acidity was recorded in the treatment combination of $\mathrm{C}_{1} \mathrm{~B}_{4} \mathrm{~S}_{2}$ of 0.78 per cent followed by $\mathrm{C}_{1} \mathrm{~B}_{4} \mathrm{~S}_{2}(0.77$ per cent) and the lowest was recorded in $\mathrm{C}_{2} \mathrm{~B}_{3} \mathrm{~S}_{5}(0.39$ per cent) (Table 3$)$.

The mean value of titrable acidity has significantly decreased from the initial day to $60^{\text {th }}$ day during the storage period. Due to the copolymerisation of organic acids with amino acids and sugar, the percent acidity was decreased (Malav et al., 2014). Similar results were observed in lime aonla blended squash by Harshavardhan and Chikkasubbanna (2008), Muhammad et al. (2018) in orange date blended squash during the storage period. The decrease in the acidity of the squash prepared by blending kinnow mandarin juice and ginger juice were observed with an increase in storage period at room temperature by Nath et al. (2005). 
Table 3. Interaction effect of blended juice combinations, storage conditions and days of storage on different parameters of RTS beverage along with sugandi prepared by spray drying method

\begin{tabular}{|c|c|c|c|c|c|c|c|c|}
\hline Interactions & pH & $\begin{array}{c}\text { TSS } \\
\left({ }^{0} \text { Brix }\right)\end{array}$ & $\begin{array}{c}\text { Titrable } \\
\text { acidity } \\
(\%)\end{array}$ & $\begin{array}{c}\text { Reducing } \\
\text { sugars } \\
(\%) \\
\end{array}$ & $\begin{array}{c}\text { Total } \\
\text { sugars } \\
(\%)\end{array}$ & $\begin{array}{l}\text { TSS/Acid } \\
\text { ratio }\end{array}$ & $\begin{array}{c}\text { Ascorbic } \\
\text { acid } \\
\left(\mathrm{mg} 100 \mathrm{~mL}^{-1}\right)\end{array}$ & $\begin{array}{l}\text { Tannins } \\
\left(\mathrm{mg} \mathrm{mL}^{-1}\right)\end{array}$ \\
\hline $\mathrm{B}_{1} \mathrm{C}_{1} \mathrm{~S}_{1}$ & 3.53 & 10.00 & 0.54 & 3.06 & 8.88 & 18.91 & 155.15 & 1.060 \\
\hline $\mathrm{B}_{1} \mathrm{C}_{1} \mathrm{~S}_{2}$ & 3.49 & 10.10 & 0.49 & 3.09 & 8.90 & 21.12 & 147.84 & 1.030 \\
\hline $\mathrm{B}_{1} \mathrm{C}_{1} \mathrm{~S}_{3}$ & 3.41 & 10.20 & 0.48 & 3.19 & 8.92 & 21.78 & 145.75 & 1.033 \\
\hline $\mathrm{B}_{1} \mathrm{C}_{1} \mathrm{~S}_{4}$ & 3.29 & 10.35 & 0.46 & 3.28 & 8.98 & 23.17 & 143.75 & 0.983 \\
\hline $\mathrm{B}_{1} \mathrm{C}_{1} \mathrm{~S}_{5}$ & 3.25 & 10.75 & 0.44 & 3.25 & 9.03 & 25.61 & 141.75 & 0.978 \\
\hline $\mathrm{B}_{2} \mathrm{C}_{1} \mathrm{~S}_{1}$ & 3.54 & 10.10 & 0.53 & 3.05 & 8.92 & 18.88 & 156.82 & 1.050 \\
\hline $\mathrm{B}_{2} \mathrm{C}_{1} \mathrm{~S}_{2}$ & 3.54 & 10.20 & 0.49 & 3.14 & 9.02 & 20.96 & 154.29 & 1.018 \\
\hline $\mathrm{B}_{2} \mathrm{C}_{1} \mathrm{~S}_{3}$ & 3.44 & 10.30 & 0.48 & 3.26 & 9.04 & 21.58 & 150.85 & 0.983 \\
\hline $\mathrm{B}_{2} \mathrm{C}_{1} \mathrm{~S}_{4}$ & 3.36 & 10.45 & 0.46 & 3.38 & 9.06 & 23.49 & 148.70 & 0.968 \\
\hline $\mathrm{B}_{2} \mathrm{C}_{1} \mathrm{~S}_{5}$ & 3.28 & 10.85 & 0.40 & 3.45 & 9.08 & 27.97 & 144.25 & 0.948 \\
\hline $\mathrm{B}_{3} \mathrm{C}_{1} \mathrm{~S}_{1}$ & 3.54 & 10.15 & 0.54 & 3.12 & 9.02 & 18.82 & 158.67 & 1.035 \\
\hline $\mathrm{B}_{3} \mathrm{C}_{1} \mathrm{~S}_{2}$ & 3.48 & 10.15 & 0.52 & 3.19 & 9.04 & 19.87 & 156.38 & 0.995 \\
\hline $\mathrm{B}_{3} \mathrm{C}_{1} \mathrm{~S}_{3}$ & 3.46 & 10.45 & 0.49 & 3.29 & 9.06 & 21.53 & 149.71 & 0.983 \\
\hline $\mathrm{B}_{3} \mathrm{C}_{1} \mathrm{~S}_{4}$ & 3.39 & 10.55 & 0.48 & 3.40 & 9.12 & 22.65 & 144.75 & 0.968 \\
\hline $\mathrm{B}_{3} \mathrm{C}_{1} \mathrm{~S}_{5}$ & 3.37 & 11.00 & 0.41 & 3.50 & 9.14 & 26.01 & 143.75 & 0.948 \\
\hline $\mathrm{B}_{4} \mathrm{C}_{1} \mathrm{~S}_{1}$ & 3.51 & 10.15 & 0.79 & 3.12 & 9.12 & 12.79 & 208.29 & 1.228 \\
\hline $\mathrm{B}_{4} \mathrm{C}_{1} \mathrm{~S}_{2}$ & 3.49 & 10.35 & 0.77 & 3.23 & 9.16 & 13.34 & 201.27 & 1.213 \\
\hline $\mathrm{B}_{4} \mathrm{C}_{1} \mathrm{~S}_{3}$ & 3.43 & 10.36 & 0.75 & 3.43 & 9.16 & 13.73 & 197.60 & 1.188 \\
\hline $\mathrm{B}_{4} \mathrm{C}_{1} \mathrm{~S}_{4}$ & 3.39 & 10.69 & 0.71 & 3.50 & 9.25 & 13.10 & 192.88 & 1.115 \\
\hline $\mathrm{B}_{4} \mathrm{C}_{1} \mathrm{~S}_{5}$ & 3.36 & 11.15 & 0.62 & 3.56 & 9.27 & 16.88 & 181.25 & 1.065 \\
\hline $\mathrm{B}_{1} \mathrm{C}_{2} \mathrm{~S}_{1}$ & 3.53 & 10.00 & 0.54 & 3.06 & 8.88 & 18.91 & 155.15 & 1.060 \\
\hline $\mathrm{B}_{1} \mathrm{C}_{2} \mathrm{~S}_{2}$ & 3.52 & 10.20 & 0.53 & 3.20 & 8.85 & 19.68 & 148.65 & 1.030 \\
\hline $\mathrm{B}_{1} \mathrm{C}_{2} \mathrm{~S}_{3}$ & 3.42 & 10.29 & 0.51 & 3.29 & 8.90 & 20.20 & 146.65 & 1.010 \\
\hline $\mathrm{B}_{1} \mathrm{C}_{2} \mathrm{~S}_{4}$ & 3.32 & 10.19 & 0.49 & 3.38 & 8.94 & 21.28 & 144.25 & 1.008 \\
\hline $\mathrm{B}_{1} \mathrm{C}_{2} \mathrm{~S}_{5}$ & 3.30 & 10.36 & 0.44 & 3.45 & 9.02 & 23.67 & 142.58 & 0.990 \\
\hline $\mathrm{B}_{2} \mathrm{C}_{2} \mathrm{~S}_{1}$ & 3.54 & 10.10 & 0.53 & 3.05 & 8.92 & 18.88 & 156.82 & 1.050 \\
\hline $\mathrm{B}_{2} \mathrm{C}_{2} \mathrm{~S}_{2}$ & 3.50 & 10.20 & 0.51 & 3.18 & 8.93 & 20.10 & 151.75 & 1.010 \\
\hline $\mathrm{B}_{2} \mathrm{C}_{2} \mathrm{~S}_{3}$ & 3.44 & 10.26 & 0.49 & 3.29 & 8.98 & 21.11 & 149.23 & 0.990 \\
\hline $\mathrm{B}_{2} \mathrm{C}_{2} \mathrm{~S}_{4}$ & 3.38 & 10.36 & 0.44 & 3.37 & 9.02 & 23.19 & 146.10 & 0.978 \\
\hline $\mathrm{B}_{2} \mathrm{C}_{2} \mathrm{~S}_{5}$ & 3.34 & 10.52 & 0.42 & 3.37 & 9.04 & 25.28 & 144.28 & 0.960 \\
\hline $\mathrm{B}_{3} \mathrm{C}_{2} \mathrm{~S}_{1}$ & 3.54 & 10.15 & 0.54 & 3.12 & 9.02 & 18.82 & 158.67 & 1.035 \\
\hline $\mathrm{B}_{3} \mathrm{C}_{2} \mathrm{~S}_{2}$ & 3.49 & 10.29 & 0.51 & 3.21 & 9.05 & 20.19 & 156.85 & 1.010 \\
\hline $\mathrm{B}_{3} \mathrm{C}_{2} \mathrm{~S}_{3}$ & 3.48 & 10.37 & 0.49 & 3.31 & 9.07 & 21.28 & 154.70 & 0.978 \\
\hline $\mathrm{B}_{3} \mathrm{C}_{2} \mathrm{~S}_{4}$ & 3.39 & 10.47 & 0.45 & 3.43 & 9.18 & 23.38 & 149.34 & 0.978 \\
\hline $\mathrm{B}_{3} \mathrm{C}_{2} \mathrm{~S}_{5}$ & 3.35 & 10.66 & 0.39 & 3.36 & 9.21 & 27.37 & 147.70 & 0.968 \\
\hline $\mathrm{B}_{4} \mathrm{C}_{2} \mathrm{~S}_{1}$ & 3.51 & 10.15 & 0.79 & 3.12 & 9.12 & 12.79 & 208.29 & 1.228 \\
\hline $\mathrm{B}_{4} \mathrm{C}_{2} \mathrm{~S}_{2}$ & 3.49 & 10.15 & 0.78 & 3.26 & 9.21 & 13.12 & 204.28 & 1.230 \\
\hline $\mathrm{B}_{4} \mathrm{C}_{2} \mathrm{~S}_{3}$ & 3.42 & 10.35 & 0.76 & 3.38 & 9.23 & 13.71 & 196.65 & 1.188 \\
\hline $\mathrm{B}_{4} \mathrm{C}_{2} \mathrm{~S}_{4}$ & 3.40 & 10.46 & 0.75 & 3.52 & 9.27 & 14.24 & 191.65 & 1.088 \\
\hline $\mathrm{B}_{4} \mathrm{C}_{2} \mathrm{~S}_{5}$ & 3.34 & 10.65 & 0.67 & 3.61 & 9.31 & 16.26 & 187.67 & 1.068 \\
\hline SEm \pm & 0.02 & 0.04 & 0.01 & 0.02 & 0.01 & 0.11 & 1.13 & 0.008 \\
\hline CD (0.05) & 0.04 & NS & 0.03 & 0.04 & NS & 0.31 & 3.39 & 0.022 \\
\hline CV\% & 0.64 & 0.64 & 2.39 & 0.67 & 0.20 & 0.78 & 1.17 & 1.013 \\
\hline
\end{tabular}


Table 4. Interaction effect of blended juice treatment combinations, storage conditions and days of storage on organoleptic score of RTS beverage along with sugandi prepared by spray drying method

\begin{tabular}{|c|c|c|c|c|}
\hline Interactions & Colour & Flavour & Taste & $\begin{array}{c}\text { Overall } \\
\text { acceptability }\end{array}$ \\
\hline $\mathrm{B}_{1} \mathrm{C}_{1} \mathrm{~S}_{1}$ & 8.78 & 7.95 & 7.70 & 7.80 \\
\hline $\mathrm{B}_{1} \mathrm{C}_{1} \mathrm{~S}_{2}$ & 7.90 & 7.90 & 7.75 & 7.80 \\
\hline $\mathrm{B}_{1} \mathrm{C}_{1} \mathrm{~S}_{3}$ & 7.70 & 7.50 & 6.55 & 6.65 \\
\hline $\mathrm{B}_{1} \mathrm{C}_{1} \mathrm{~S}_{4}$ & 6.58 & 7.25 & 5.80 & 5.80 \\
\hline $\mathrm{B}_{1} \mathrm{C}_{1} \mathrm{~S}_{5}$ & 6.00 & 6.85 & 5.35 & 5.45 \\
\hline $\mathrm{B}_{2} \mathrm{C}_{1} \mathrm{~S}_{1}$ & 8.90 & 8.55 & 8.05 & 8.64 \\
\hline $\mathrm{B}_{2} \mathrm{C}_{1} \mathrm{~S}_{2}$ & 8.28 & 7.60 & 7.35 & 7.30 \\
\hline $\mathrm{B}_{2} \mathrm{C}_{1} \mathrm{~S}_{3}$ & 7.95 & 7.30 & 7.00 & 6.50 \\
\hline $\mathrm{B}_{2} \mathrm{C}_{1} \mathrm{~S}_{4}$ & 7.30 & 7.05 & 6.10 & 5.65 \\
\hline $\mathrm{B}_{2} \mathrm{C}_{1} \mathrm{~S}_{5}$ & 6.75 & 6.85 & 5.75 & 5.15 \\
\hline $\mathrm{B}_{3} \mathrm{C}_{1} \mathrm{~S}_{1}$ & 8.43 & 8.25 & 8.85 & 8.65 \\
\hline $\mathrm{B}_{3} \mathrm{C}_{1} \mathrm{~S}_{2}$ & 8.00 & 7.35 & 7.20 & 6.65 \\
\hline $\mathrm{B}_{3} \mathrm{C}_{1} \mathrm{~S}_{3}$ & 7.58 & 6.85 & 6.85 & 6.70 \\
\hline $\mathrm{B}_{3} \mathrm{C}_{1} \mathrm{~S}_{4}$ & 7.15 & 5.55 & 5.75 & 4.95 \\
\hline $\mathrm{B}_{3} \mathrm{C}_{1} \mathrm{~S}_{5}$ & 6.50 & 5.00 & 4.90 & 4.95 \\
\hline $\mathrm{B}_{4} \mathrm{C}_{1} \mathrm{~S}_{1}$ & 8.63 & 8.65 & 8.00 & 8.40 \\
\hline $\mathrm{B}_{4} \mathrm{C}_{1} \mathrm{~S}_{2}$ & 8.03 & 7.40 & 7.75 & 7.55 \\
\hline $\mathrm{B}_{4} \mathrm{C}_{1} \mathrm{~S}_{3}$ & 7.73 & 6.85 & 7.20 & 6.85 \\
\hline $\mathrm{B}_{4} \mathrm{C}_{1} \mathrm{~S}_{4}$ & 7.28 & 5.40 & 5.25 & 6.50 \\
\hline $\mathrm{B}_{4} \mathrm{C}_{1} \mathrm{~S}_{5}$ & 6.80 & 5.05 & 4.80 & 4.70 \\
\hline $\mathrm{B}_{1} \mathrm{C}_{2} \mathrm{~S}_{1}$ & 8.78 & 7.95 & 7.70 & 7.80 \\
\hline $\mathrm{B}_{1} \mathrm{C}_{2} \mathrm{~S}_{2}$ & 8.35 & 7.90 & 7.45 & 7.55 \\
\hline $\mathrm{B}_{1} \mathrm{C}_{2} \mathrm{~S}_{3}$ & 8.18 & 7.10 & 7.40 & 7.50 \\
\hline $\mathrm{B}_{1} \mathrm{C}_{2} \mathrm{~S}_{4}$ & 7.88 & 6.80 & 7.05 & 7.30 \\
\hline $\mathrm{B}_{1} \mathrm{C}_{2} \mathrm{~S}_{5}$ & 7.45 & 6.50 & 6.85 & 6.90 \\
\hline $\mathrm{B}_{2} \mathrm{C}_{2} \mathrm{~S}_{1}$ & 8.90 & 8.55 & 8.05 & 8.64 \\
\hline $\mathrm{B}_{2} \mathrm{C}_{2} \mathrm{~S}_{2}$ & 8.55 & 8.10 & 7.90 & 8.35 \\
\hline $\mathrm{B}_{2} \mathrm{C}_{2} \mathrm{~S}_{3}$ & 8.05 & 7.65 & 7.80 & 8.06 \\
\hline $\mathrm{B}_{2} \mathrm{C}_{2} \mathrm{~S}_{4}$ & 7.85 & 7.35 & 7.65 & 7.90 \\
\hline $\mathrm{B}_{2} \mathrm{C}_{2} \mathrm{~S}_{5}$ & 7.45 & 7.30 & 7.45 & 7.60 \\
\hline $\mathrm{B}_{3} \mathrm{C}_{2} \mathrm{~S}_{1}$ & 8.43 & 8.25 & 8.85 & 8.65 \\
\hline $\mathrm{B}_{3} \mathrm{C}_{2} \mathrm{~S}_{2}$ & 7.85 & 8.00 & 8.00 & 8.40 \\
\hline $\mathrm{B}_{3} \mathrm{C}_{2} \mathrm{~S}_{3}$ & 7.65 & 7.55 & 7.15 & 7.60 \\
\hline $\mathrm{B}_{3} \mathrm{C}_{2} \mathrm{~S}_{4}$ & 7.25 & 7.40 & 7.05 & 7.05 \\
\hline $\mathrm{B}_{3} \mathrm{C}_{2} \mathrm{~S}_{5}$ & 7.08 & 7.20 & 6.80 & 6.95 \\
\hline $\mathrm{B}_{4} \mathrm{C}_{2} \mathrm{~S}_{1}$ & 8.63 & 8.65 & 8.00 & 8.40 \\
\hline $\mathrm{B}_{4} \mathrm{C}_{2} \mathrm{~S}_{2}$ & 7.90 & 8.15 & 7.35 & 7.90 \\
\hline $\mathrm{B}_{4} \mathrm{C}_{2} \mathrm{~S}_{3}$ & 7.53 & 7.75 & 7.00 & 7.25 \\
\hline $\mathrm{B}_{4} \mathrm{C}_{2} \mathrm{~S}_{4}$ & 7.33 & 7.30 & 6.80 & 6.85 \\
\hline $\mathrm{B}_{4} \mathrm{C}_{2} \mathrm{~S}_{5}$ & 7.25 & 7.00 & 6.70 & 6.80 \\
\hline$\overline{\mathrm{SEm}} \pm$ & 0.15 & 0.15 & 0.14 & 0.21 \\
\hline CD (0.05) & NS & 0.44 & 0.40 & 0.62 \\
\hline CV\% & 2.76 & 3.09 & 2.85 & 4.33 \\
\hline
\end{tabular}

\section{Reducing sugars (\%)}

Among the blended juice treatment combinations, the highest reducing sugars of 3.37 per cent were recorded in $\mathrm{B}_{4}$ followed by $\mathrm{B}_{3}(3.29 \%)$ and the lowest was recorded in $\mathrm{B}_{1}(3.22 \%)$. Among the different storage conditions, the highest reducing sugars (\%) was recorded in $\mathrm{C}_{2}(3.30)$, and the lowest was recorded in $\mathrm{C}_{1}(3.27 \%)$. Among the different days of storage, the highest reducing sugars (\%) was recorded in $\mathrm{S}_{5}(3.44 \%)$, and the lowest was recorded in $\mathrm{S}_{1}(3.09 \%)$ (Table 1$)$.

The reducing sugars of different blended juice treatment combinations varied from 3.05 to 3.12 on the initial day of storage. Among the interaction effect of blended juice treatment combinations, storage conditions and days of storage revealed the highest reducing sugars (\%) was revealed in the treatment combination of $\mathrm{C}_{2} \mathrm{~B}_{4} \mathrm{~S}_{5}(3.61 \%)$ followed by $\mathrm{C}_{1} \mathrm{~B}_{4} \mathrm{~S}_{5}$ and the lowest was recorded in $\mathrm{C}_{1} \mathrm{~B}_{2} \mathrm{~S}_{2}$ (Table 3).

The mean value of reducing sugars significantly increased from the initial day to $60^{\text {th }}$ day during storage. The rising temperature during storage also accelerated the hydrolysis of acids and polypolysaccharides into simple sugars (Bhardwaj and Nandal, 2014). Sarmah et al. (1981) observed a considerable increase in reducing sugar content in single strength kinnow mandarin juice in the samples at room temperature than those kept at low temperatures. According to Kotecha and Kadam (2003) and Sahu et al. (2005), the total and reducing sugar was increased in tamarind syrup and mango lemongrass beverages, respectively, during storage which might be due to the breakdown of polysaccharides into monosaccharides. Muhammad et al. (2018) studied the orange date blended squash at different ratios and observed that the mean value of reducing sugar significantly increased from 16.50 to 17.76 per cent during storage.

\section{Total sugars ( $\%)$}

Among the blended juice treatment combinations, the highest total sugars of 9.23 per cent were recorded in $\mathrm{B}_{4}$ followed by $\mathrm{B}_{3}$ and the lowest was recorded in $\mathrm{B}_{1}$. The difference observed at different storage conditions for total sugars (\%) was non-significant. Among the different days of 
storage, the highest total sugars (\%) was recorded in $\mathrm{S}_{5}\left(60^{\text {th }}\right.$ day of storage $)$ as 9.14 per cent, and the lowest was recorded in $\mathrm{S}_{1}$ (0 days of storage) as 8.98 per cent. The differences observed for the interaction effect of blended juice treatment combinations, storage conditions and days of storage for total sugars (Table 3) were nonsignificant.

An increase in the total sugars from the initial day to the $60^{\text {th }}$ day of the storage period was observed. The fruit juice contains various reducing and non-reducing sugars, which tend to change during storage due to various interconversion processes. The increase in total sugars could result from the hydrolysis of polysaccharides like pectin, cellulose and starch into simple sugars, as reported by Singh and Mathur (1953) in cashew apple juice. Similar results were observed by Sindumathi and Premalatha (2015) in flavoured papaya-pineapple blended RTS beverage.

\section{TSS/Acid ratio}

Among the blended juice treatment combinations, the highest TSS/acid ratio of 22.14 was recorded in $\mathrm{B}_{2}$ followed by $\mathrm{B}_{3}$ and the lowest was recorded in $\mathrm{B}_{4}$. Among the different storage conditions, the highest TSS/acid ratio was recorded in $\mathrm{C}_{1}$ and the lowest was recorded in $\mathrm{C}_{2}$ ) of 19.67. Among the different days of storage, the highest TSS/Acid ratio was recorded in $\mathrm{S}_{5}$ as 23.63 , and the lowest (17.35) was recorded in $\mathrm{S}_{1}$ (Table 1).

The TSS/acid ratio of different blended juice treatment combinations varied from 12.79 to 18.91 on the initial day of storage. Among the interaction effects for blended juice treatment combinations, storage conditions and days of storage recorded the highest TSS/acid ratio (27.97) in the treatment $\mathrm{C}_{1} \mathrm{~B}_{2} \mathrm{~S}_{5}$ followed by $\mathrm{C}_{2} \mathrm{~B}_{3} \mathrm{~S}_{5}$ of 27.37 and the lowest was recorded in $\mathrm{C}_{2} \mathrm{~B}_{4} \mathrm{~S}_{2}(100 \%$ cashew apple juice at an inlet temperature of $150{ }^{\circ} \mathrm{C}$ with a flow rate of $10 \mathrm{~mL} \mathrm{~min}{ }^{-1}$ under the refrigerated condition at $15^{\text {th }}$ day of storage) of 13.12 (Table 3).

An increase in TSS/ acid ratio was observed during the storage period from the initial day to the $60^{\text {th }}$ day. It might be due to an increase in the TSS and a decrease in the acidity during the storage period. The cashew apple RTS, squash, syrup, blended syrup of cashew apple with kokum and karonda, prepared from all the varieties of cashew apple under study, exhibited a significant increase in ${ }^{\circ}$ Brix: acid ratio during the storage period of 12 months (Manjarekar, 2005).

\section{Ascorbic acid}

Among the blended juice treatment combinations, the highest ascorbic acid of 196.98 mg $100 \mathrm{~mL}^{-1}$ was recorded in $\mathrm{B}_{4}$ followed by $\mathrm{B}_{3}$ as

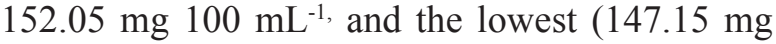
$100 \mathrm{~mL}^{-1}$ ) was recorded in $\mathrm{B}_{1}$. Among the different storage conditions, the highest ascorbic acid ratio

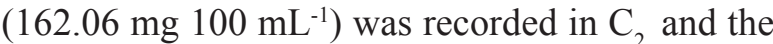

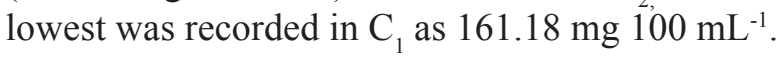
Among the different days of storage, the highest ascorbic acid was recorded $\left(169.73 \mathrm{mg} 100 \mathrm{~mL}^{-1}\right)$ in $\mathrm{S}_{1}$ and the lowest was recorded in $\mathrm{S}_{5}$ of $154.15 \mathrm{mg}$ $100 \mathrm{~mL}^{-1}$ (Table 1).

The ascorbic acid content of different blended juice treatment combinations varied from 155.15 to 208.29 on the initial day of storage. Among the interaction effect of blended juice combination, storage conditions and days of storage recorded the highest ascorbic acid $\left(204.28 \mathrm{mg} 100 \mathrm{~mL}^{-1}\right)$ of

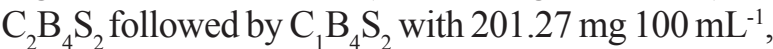
and the lowest (141.75 mg per $100 \mathrm{~mL}$ ) was recorded in $\mathrm{C}_{1} \mathrm{~B}_{1} \mathrm{~S}_{5}$ (Table 3 ).

The mean value of ascorbic acid has significantly decreased from the initial day to $60^{\text {th }}$ day during storage. According to Jain et al. (2003) decrease in ascorbic acid might be because it gets easily oxidised by both enzymatic and nonenzymatic catalyst in the presence of oxygen, as it is sensitive to light, heat and oxygen. Carvalho et al. (2007) reported the decreasing trend in vitamin C content in cashew apple juice blended with coconut water during storage. A similar trend was also reported in cashew apple juice by Costa et al. (2003). Kabasakalis et al. (2000) had found 29 to 41 per cent of ascorbic acid loss after four months when fruit juices were stored at room temperature, while Burdulu et al. (2006) found 27.3 to 45.3 per cent loss in ascorbic acid when orange juice was stored at $28^{\circ} \mathrm{C}$ for two months. Majumdar et al. (2009) reported 74 per cent loss in ascorbic acid in cucumber + litchi + lemon blended juice stored for six months. Amaravathi et al. (2014) observed a 
decrease in the ascorbic acid content of the spiced pineapple RTS beverages during storage. Muhammad et al. (2018) also reported decreasing ascorbic acid in orange date blended beverage during three months of storage.

\section{Tannins}

Among the blended juice treatment combinations, the lowest tannin of $0.990 \mathrm{mg} \mathrm{mL}^{-1}$ was recorded in $\mathrm{B}_{3}$. $\mathrm{B}_{2}$ recorded the tannin content of $0.995 \mathrm{mg} \mathrm{mL}^{-1}$. The highest tannin content $\left(1.161 \mathrm{mg} \mathrm{mL}^{-1}\right)$ was recorded in $\mathrm{B}_{4}$. There was no significant difference in different storage conditions with respect to tannin content. Among the different days of storage, the lowest tannin content $\left(0.990 \mathrm{mg} \mathrm{mL}^{-1}\right)$ was recorded in $\mathrm{S}_{5}$, and the highest $\left(1.093 \mathrm{mg} \mathrm{mL}^{-1}\right)$ was recorded in $\mathrm{S}_{1}$.

The tannins of different blended juice treatment combinations varied from 1.035 to 1.228 on the initial day of storage. Among the interaction effect of blended juice combinations, storage conditions and days of storage, the lowest tannin in $\mathrm{C}_{1} \mathrm{~B}_{2} \mathrm{~S}_{5}$ and $\mathrm{C}_{1} \mathrm{~B}_{3} \mathrm{~S}_{5}$ with a value of $0.948 \mathrm{mg} \mathrm{mL}^{-1}$ and the highest $\left(1.228 \mathrm{mg} \mathrm{mL}^{-1}\right)$ was recorded in $\mathrm{C}_{2} \mathrm{~B}_{4} \mathrm{~S}_{1}$ (Table 3).

A gradual decrease in tannin content was observed during storage from the initial day to the $60^{\text {th }}$ day. The same results were observed by Deka et al. (2004) in mango-pine apple spiced RTS beverages during storage.

\section{Organoleptic evaluation}

\section{Colour}

Among the blended juice treatment combinations, the highest organoleptic score for the colour of 8.00 was recorded in $\mathrm{B}_{2}$ followed by $\mathrm{B}_{1}(7.76)$ and the lowest was recorded in $\mathrm{B}_{3}$ (7.59). Among the different storage conditions, the highest organoleptic score of colour was recorded in $\mathrm{C}_{2}$ (7.92), and the lowest was recorded in $\mathrm{C}_{1}$ (7.61). Among the different days of storage, the highest organoleptic score for colour (8.68) was recorded in $\mathrm{S}_{1}$ and the lowest (6.91) was recorded in $\mathrm{S}_{5}$ (Table 2).

There were no significant differences in the interaction effect of blended juice treatment combinations, storage conditions, and storage days for organoleptic score for colour (Table 4). The mean organoleptic score for colour was decreased from 8.9 to 6.0. Bezman et al. (2001) reported that beverage colour decreased during storage of orange juices, and it might be due to the presence of 2 methyl 3 furanthiol and methanol. A similar colour score was also observed in orange and pineapple blended squash (Akusu et al., 2016). Similar results were reported by Muhammad et al. (2018) in orange date blended squash at different ratios. The mean score of judges for colour and flavour had decreased from 7.6 to 5.8 and 7.9 to 6.2, respectively. Rita and Virendra (2012) observed that the colour of the custard apple lime blended beverage in the ratio of $3: 1$ decreased from 5.08 to 4.70 during six months of storage.

\section{Flavour}

Among the blended juice treatment combinations, the highest organoleptic score for flavour of 7.63 was recorded in $\mathrm{B}_{2}$ followed by $\mathrm{B}_{1}$ (7.37) and the lowest (7.14) was recorded in $B_{3}$. Among the different storage conditions, the highest organoleptic score of flavour (7.06) was recorded in $\mathrm{C}_{2}$ (7.62), and the lowest was recorded in $\mathrm{C}_{1}$. Among the different days of storage, the highest organoleptic score for flavour was recorded in $\mathrm{S}_{1}$ (8.35), and the lowest (6.47) was recorded in $S_{5}$ (Table-2).

The organoleptic score for flavour of different blended juice treatment combinations varied from 7.95 to 8.65 on the initial day of storage. Among the interaction effects for blended juice treatment combinations, storage conditions, and days of storage, $\mathrm{C}_{2} \mathrm{~B}_{4} \mathrm{~S}_{2}$ has recorded the highest (8.15) organoleptic score for flavour, followed by $\mathrm{C}_{2} \mathrm{~B}_{2} \mathrm{~S}_{2}$ (8.10), and the lowest (5.00) was recorded in $\mathrm{C}_{2} \mathrm{~B}_{3} \mathrm{~S}_{5}$ (Table 4).

The mean score for flavour has progressively decreased from 8.65 to 5.00. Jain et al. (2003) reported that significant changes in the flavour of mix fruit squash might be due to enzymatic and nonenzymatic reactions and oxygen. Similarly, Paracha et al. (2004) observed that during three months of storage interval, the flavour of guava squash was decreased, and Kathiravan et al. (2014) reported that the sensory score was significantly reduced blended coconut-nannari beverage during storage. 


\section{Taste}

Among the blended juice treatment combinations, the highest organoleptic score of 7.31for taste was recorded in $\mathrm{B}_{2}$ followed by $\mathrm{B}_{3}$ (7.14) and the lowest (6.89) was recorded in $\mathrm{B}_{4}$. Among the different storage conditions, the highest organoleptic for taste was recorded in $\mathrm{C}_{2}$ (7.45), and the lowest (6.70) was recorded in $\mathrm{C}_{1}$.

Among the different days of storage, the highest organoleptic score for taste was recorded in $\mathrm{S}_{1}$ as 8.15 , and the lowest (6.08) was recorded in $\mathrm{S}_{5}$.

The organoleptic score for taste of different blended juice treatment combinations varied from 7.70 to 8.85 on the initial day of storage. Among the interaction effect of blended juice treatment combinations, storage conditions and days of storage, the highest organoleptic score for taste was recorded in the treatment combination of $\mathrm{C}_{2} \mathrm{~B}_{3} \mathrm{~S}_{2}$ as 8.00 , followed by $\mathrm{C}_{2} \mathrm{~B}_{2} \mathrm{~S}_{2}$ with a value of 7.90 and the lowest (4.80) was recorded in $\mathrm{C}_{1} \mathrm{~B}_{4} \mathrm{~S}_{5}$ (Table 4).

The taste of the RTS beverage decreased gradually during the storage. The RTS beverages prepared from tamarind juice and ginger, mint, cardamom, pepper and mixed spices were highly acceptable even after storing for six months at room temperature without deteriorating the taste (Manjula et al., 2003).

\section{Overall acceptability}

Among the blended juice treatment combinations, the highest organoleptic score for overall acceptability of 7.38 was recorded in $\mathrm{B}_{2}$ followed by $B_{4}$ with a value of 7.12 and the lowest of 7.06 was recorded in $\mathrm{B}_{3} \mathrm{~B}_{1}$. Among the different storage conditions, the highest organoleptic score of overall acceptability (7.67) was recorded in $\mathrm{C}_{2}$, and the lowest was recorded in $\mathrm{C}_{1}$ of 6.63 . Among the different days of storage, the highest organoleptic score for overall acceptability was recorded in $\mathrm{S}_{1}$ of 8.37, and the lowest was recorded in $\mathrm{S}_{5}$ of 6.06. (Table 2).

The organoleptic score for taste of different blended juice treatment combinations varied from 7.80 to 8.65 on the initial day of storage. Among the interaction effects of blended juice treatment combinations, storage conditions and days of storage recorded the highest organoleptic score for overall acceptability (8.40) in treatment combination of $\mathrm{C}_{2} \mathrm{~B}_{3} \mathrm{~S}_{2}$ followed by $\mathrm{C}_{2} \mathrm{~B}_{2} \mathrm{~S}_{2}$ with a value of 8.35, and the lowest (4.70) was recorded in $\mathrm{C}_{1} \mathrm{~B}_{4} \mathrm{~S}_{5}$ (Table 4).

According to Deeba and Saqib (2015), the overall acceptability of ashwagandha-fortified blended beverage and makoi fortified blended beverage with orange was higher on the $90^{\text {th }}$ day of storage, demonstrating the beneficial effect of herbal extract addition in maintaining the stability of the developed beverage. It might be due to the high antioxidant activity of both the herbal extracts, which, to a greater extent, could prevent timedependent hydrolysis of sugars and increase in acidity of the blends.

The overall acceptability of squash decreases with increasing days of storage period. Overall qualities were affected by temperature and storage (Hye et al., 2000). Sobhana et al. (2015) observed the organoleptic scoring of RTS beverage and squash; they revealed that sample prepared with cashew apple juice and pineapple juice in equal proportion along with ginger drops, followed by cashew apple juice blended with pineapple was found to have better acceptability.

\section{Microbial load (CFU)}

Microbial load (CFU) was not observed in refrigerated condition up to the $60^{\text {th }}$ day of storage. Bacterial colonies were not found under ambient condition up to the $45^{\text {th }}$ day of storage. Yeast and moulds were observed from the $45^{\text {th }}$ day of storage. However, the bacterial colonies were found under ambient conditions on the $60^{\text {th }}$ day of storage (Fig. 1).

The RTS beverages, along with sugandi stored under refrigerated condition, were free from microbial proliferation till the end of the storage period $\left(60^{\text {th }}\right.$ day of storage), indicating their fitness for consumption. This could be attributed to the effective pasteurisation treatment, addition of citric acid, which acts as a preservative, and the addition of sugandi root extract, which is well known to possess good antimicrobial activity (Girish et al., 2006; Deeba and Saqib, 2015). The growth was highest on the $45^{\text {th }}$ day of the storage period, 
which might be attributed to the chemical changes, specifically alterations in the $\mathrm{pH}$ of the system that would take place resulting from the presence of the chemical preservatives in the samples. Thakur et al. (2000) also studied on physicochemical and microbiological qualities of bittered kinnow juice. They concluded that low microbial count was detected in the concentrate initially, which increased with the advancement of storage during the six months of storage. Sindumathi (2002) also did not detect any bacterial load in papaya based blended RTS beverages up to 80 days of storage. However, bacterial growth was observed in the beverages during the $100^{\text {th }}$ day, which again increased on the $120^{\text {th }}$ day of storage.

\section{Conclusion}

Among the interaction effect of blended juice treatment combinations, storage conditions and days of storage, the highest organoleptic score for taste and organoleptic score for overall acceptability was recorded in treatment combination of $\mathrm{C}_{2} \mathrm{~B}_{3} \mathrm{~S}_{2}$ i.e., 8.00 and 8.40 , respectively. The RTS beverages, along with sugandi stored under refrigerated condition, were free from microbial proliferation till the end of the storage period ( $60^{\text {th }}$ day of storage), indicating its fitness for consumption with maximum flavour, taste and overall acceptability at 75 per cent cashew apple juice +25 per cent pineapple juice at an inlet temperature of $150{ }^{\circ} \mathrm{C}$ with a flow rate of $10 \mathrm{~mL} \mathrm{~min}{ }^{-1}$ under refrigerated condition up to $60^{\text {th }}$ day of storage.

\section{References}

Akusu, O.M., Kiin-Kabari, D.B. and Ebere, C.O. 2016. Quality characteristic of orange/pineapple fruit juice blends. American Journal of Food Science and Technology 4(2): 43-47.

Amaravathi, T.P., Vennila, P., Hemalatha, G. and Parimalam. P. 2014. Spiced pineapple ready-to-serve beverages. Indian Journal of Science and Technology 7(11): 1827-1831.

Azevedo, D.C.S. and Rodrigues, A.E. 2000. Obtainment of high -fructosesolutions from cashew (Anacardium occidentale L.) apple by SMB chromatography. Separation Science and Technology. 35: 2561-2581.
Bezman,Y., Russell, R.L. and Naim, M. 2001. 2-Methyl-3furanthiol and methional are possible off-flavors in stored orange juice. Journal of Agriculture Food Chemistry 49: 5425-5432.

Bhardwaj, R.L. and Mukherjee, S. 2012. Studies on physicochemical, sensory and microbiological quality of kinnow juice blends under refrigerated storage. Journal of Horticultural Science. 7: 166-173.

Bhardwaj, R.L. and Nandal, U. 2014. Effect of storage temperature on physico-chemical and sensory evaluation of kinnow mandarin juice blends. Journal of Food Processing and Technology. 5(8):1-4.

Burdulu, H.S., Koca, N. and Karadeniz, F. 2006. Degradation of vitamin $\mathrm{C}$ in citrus juices concentrates during storage. Journal of Food Engineering. 74: 211-216.

Cano-Chauca, M., Stringheta, P.C., Ramos, A.M. and CalVidal, I. 2005. Effect of the carriers on the microstructure of mango powder obtained by spray drying and its functional characterisation. Innovative Food Science and Emerging Technologies 6(4): 420-428.

Carvalho, J.M.D., Maia G.A. and Figueredo R.W.D 2007. Development of a blended non-alcoholic beverage composed of coconut water and cashew apple juice containing caffeine. Journal of Food Quality 30: 664-681.

Costa, M.C.O., Maia, G.A., Figuiredo, R.W., Souza Filho, M.S.M. and Brasil, I.M. 2003. Storage stability of cashew apple juice by hot fill and aseptic processes. Ciênciae Tecnologia de Alimentos 23: 106-109.

Chempakam, B. 1983. Distribution of ascorbic acid and ascorbic acid oxidase activity in the developing cashew apple (Anacardium occidentale L.). Journal of Horticultural Science 58(3); 447-448, DOI: 10.1080/ 00221589.1983 .11515141 .

Deka, B.C., Sethi, V., Sunija, P. and Srivasthava, V.K. 2004. Physicochemical changes of lime- aonla spiced beverages during storage. Journal of Food Science and Technology 41: 329-332.

Deka, B.C. and Sethi, V. (2001). Preparation of mixed fruit juice spiced RTS beverages. Indian Food Packer 42(3): 58-61.

Deeba, S.J. and Saqib, Q. 2015. Fortification of orange juice with Withania somnifera and Solanum nigrum extract - a potential functional fruit beverage and its quality evaluation. Pakistan Journal of Food Science 25(2): 58-65.

Girish, K.S., Machiah, K.D., Ushanandini, S., Kumar, H., Nagaraju, K.S., Govindappa, Vedavathi, M. and Kemparaju, 
K. 2006. Antimicrobial properties of a non toxic glycoprotein (WSG) from Withania somnifera (Aswagandha). Journal of Basic Microbiology 46: 365-374.

Hubbali, V.N. 2019. Cashew productivity enhancement and value addition for doubling of farmers income. The Cashew and Cocoa Journal 3(2): 13.

Hye, W.Y., Streaker, C.B., Zhang. Q.H. and Min, D.B. 2000. Effect of pasteurised electric field on the quality of orange juice and comparison with heat pasteurisation. Journal of Agricultural and Food Chemistry 48:4597-4605.

Harshavardhan, R.A. and Chikkasubbanna, V. 2008. Standardisation of recipe and storage behavior of lime blended amla squash. The Asian Journal of Horticulture 3(2): 203-207.

Jain, S., Sankhla, A.P.K, Dashora, A. and Sankhla. A.K. 2003. Physiochemical and sensory properties of orange drink. Journal of Food Science Technology 40: 656-659.

Kabasakalis, V., Siopidou, D. and Moshatou, E. 2000. Ascorbic acid content of commercial fruit juices and its rate of loss upon storage. Food Chemistry 70: 325-328.

Kathiravan, T., Kumar, R., Lakshmana, J.H., Kumaraswamy, M.R. and Nadanasabapathi, S. 2014. Pulsed electric field processing of functional drink based on tender coconut water (Cococus nucifera L.)-nannari (Hemidesmus indicus) blended beverage Croatian Journal of Food Science and Technology 6(2): 84-96.

Kotecha, P.M. and Kadam, S.S. 2003. Preparation of readyto-serve beverage, syrup and concentrate from tamarind. Journal of Food Science and Technology 40(1): 76-79.

Maciel, M.I., Hansen, T.J., Aldinger, S.B. and Laboes, J.N 1986. Flavour chemistry of cashew apple juice. Journal of Agricultural and Food Chemistry 34: 923-927.

Maia, G.A. and Cecilia, E. 2002. Storage stability of cashew apple juice preserved by hot fill and aseptic process. Journal of Food Science Technology 42: 66-69.

Majumdar, T.K., Vasudish, C. R., Premavalli, K. S. and Bawa, A. S. 2009. Development and storage stability of cucumber-litchi-lemon Juice. Journal Food Science and Technology 46: 269-270.

Malav, M., Gupta, R. and Nagar, T. 2014. Studies on biochemical composition of orange based blended RTS beverages. Bioscience and Biotechnology Research Communication 7(1): 78-83.

Manjarekar, R.G. 2005. Studies on flowering behavior, maturity indices, integrated post-harvest handling and processing of cashew (Anacardium occidentale L.) cv. Vengurla-1, Vengurla-4, Vengurla-6 and Vengurla-7. Ph. D. (Agri.) Thesis submitted to Dr. B. S. Konkan Krishi Vidyapeeth, Dapoli (India).
Manjula, A., Kannan, S. and Banumathi, P. 2003. Studies on preparation and storage of spiced RTS beverages from tamarind fruit. Souvenir, 5th International Food Convention, 5-8 Dec. 2003. Mysore, p 201.

Muhammad, A.K., Majid, S.H., Ali, M.I., Muhammad, M.I., Haris, B. and Gul W. 2018. Development and storage study of orange date blended squash. Sarhad Journal of Agriculture 34(3): 509-515.

Nanjundaswamy, A.M. 1984. Economic utilisation of cashew apple. Cashew Causerie 6(2): 2-7.

Nath, A., Yadav, D.S., Sarma, P.B. and Dey, B. 2005. Standardisation of ginger-kinnow squash and its storage. Journal of Food Science and Technology 42: 520-522.

Paracha, G.M.U., Khattak, A.B., Ashraf, C.M., Alam, Z. and Khalil, A.W. 2004. Development and storage stability of low caloric guava squash. Advanced Food Science 31(3): 127-131.

Prasad, R.N. and Mali, D.C. 2000. Changes in physicochemical characteristics of pomegranate squash during storage. Indian Journal of Horticulture 57(1): 18-20.

Rafeekher, M, Mini, C., Sudheer, K.P. and Geethalekshmy, P.R. 2015. Optimisation of process parameters in spray drying of cashew apple juice. International Journal of Tropical Agriculture 33(4): 2563-2573.

Rehman, M.A., Khan, M.R., Sharif, M.K., Ahmad, S. and Shah, F. H. 2014. Study on the storage stability of fruit juice concentrates. Pakistan Journal of Food Science 24: 101-107.

Rita, M. and Virendra, S. 2012. Studies on microbial and sensory quality of custard apple RTS beverage. The Asian Journal of Horticulture 7(2): 460-464.

Sahu, C., Patel, S. and Choudary, P.L. 2005. Technology for manufacturer of whey based mango-herbal (lemongrass) beverage. Journal of Food Science and Technology 42: 421-424

Sarmah, U., Bains, G. S. and Kripal, S. K. 1981. Studies on the processing of Kinnow mandarin juice. Punjab Horticulture Journal 21: 32-45.

Sasi Kumar, R. 2015. Preparation of therapeutic RTS beverage from aloe vera gel and aonla fruit juice and evaluation of storage stability. Asian Journal of Dairy and Food Research 34(2): 151-155.

Shreshta, A.K., Ua-Aruk, T., Adhikari, B.R., Howes, T. and Bhandari, B.R. 2007. Glass transition behavior of spray dried orange juice powder measured by differential scanning calorimetry (DSC) and thermal mechanical compression test (TMCT). International Journal of Food Processing 10(3): 661-673. 
Sindumathi, G. 2002. Standardisation of blended and flavoured papaya RTS (Ready- To-Serve) beverages. M.Sc. (FS\&N) thesis, Home Science College and Research Institute, Madurai, 89p.

Sindumathi, G. and Premalatha, M.R. 2015. Development and storage studies of naturally flavored papaya-pineapple blended ready-to-serve (RTS) beverages. International Journal of Science and Research 4(2): 856-860.

Sobhana, A, Mathew, J, Ambili, A.A. and Mrudhula, R.C. 2015. Blending of cashew apple juice with fruit juices and spices for improving nutritional quality and palatability. Acta Horticulturae 369-375.
Srivastava, R.P. and. Kumar, S. 2002. Fruits and Vegetable Preservation: Principles and Practices. International Book Distributing Company, Lucknow. pp. 184-185.

Singh, K.K. and Mathur, P.B. 1953. Studies on cold storage of cashew apples. Indian Journal of Horticulture 10: 115-121.

Thakur, N.K., LalKausal, B.B. and Joshu, V.K. 2000. Effect of different conditions of storage on physico-chemical and microbiological qualities of debittered kinnow juice concentrate. Journal of Food Science and Technology 37(4): 415-418. 